\title{
ARTICLES \\ PREDICTORS OF PICTURE NAMING AND PICTURE CATEGORIZATION IN SPANISH
}

Macarena Martínez Cuitiño
mmartinez@ineco.org.ar
Federico Gonzalo Soriano
Institute of Cognitive and Translational Neuroscience, Argentina
Virginia Jaichenco
vedericogonzalosoriano @ gmail.com
virginiajaichenco@ gmail.com
Buenos Aires University, Argentina
Brenda Steeb
brenda.steeb @gmail.com
Institute of Cognitive and Translational Neuroscience, Argentina
Juan Pablo Barreyro
jpbarreyro@gmail.com

Institute for Reasearch in Psychology, Buenos Aires University, Argentina

Received April 9, 2019; Revised April 22, 2019; Accepted May 3, 2019

\begin{abstract}
The aim of this paper was to identify which psycholinguistic variables are better predictors of performance for healthy participants in a picture naming task and in a picture categorization task. A correlation analysis and a Path analysis were carried out. The correlation analysis showed that naming accuracy and naming latency are significant and positively correlated with lexical frequency and conceptual familiarity variables, whereas they are negatively correlated with $\mathrm{H}$ index. Reaction times in the categorization task were negatively correlated with lexical frequency and conceptual familiarity variables and positively correlated with visual complexity variable. The Path analysis showed that subjective lexical frequency and $\mathrm{H}$ index are the better predictors for picture naming task. In picture categorization task, for reaction times, the better predictor variables were subjective lexical frequency, conceptual familiarity and visual complexity. These findings are discussed considering previous works on the field.
\end{abstract}

Keywords: psycholinguistic variables, predictors variables, picture naming, picture categorization, accuracy, reaction times.

Квітіньйо Макарена Мартінез, Соріано Федеріко Гонзало, Яйченко Вірджинія, Стіб Бренда, Барейро Хуан Пабло. Предиктори найменування зображень та їхної категоризації в іспанській мові.

Анотація. Мета статті - визначити, які психолінгвістичні змінні є кращими предикторами продуктивності найменування зображень та їх категоризації серед здорових

(C) Cuitiño, Macarena Martínez; Soriano, Federico Gonzalo; Jaichenco, Virginia; Steeb, Brenda; Barreyro, Juan Pablo, 2019. This is an Open Access article distributed under the terms and conditions of the Creative Commons Attribution 4.0 International Licence (http://creativecommons.org/licenses/by/4.0).

East European Journal of Psycholinguistics, 6(1), 6-18. https:/doi.org/10.5281/zenodo.3365959 
учасників. У дослідженні застосовано кореляційний аналіз та аналіз віднаходження шляхів. Кореляційний аналіз доводить, що точність та латентність назв $є$ високими, і вони позитивно корелюють $з$ лексичною частотою та концептуальною схожістю змінних, проте негативно співвідносяться з індексом Н. Кількість реакцій в завданні на категоризацію негативно співвідносилася 3 лексичною частотою та концептуальною схожістю змінних, проте позитивно корелювала зі змінною візуальної складності. Аналіз віднаходження шляхів показав, що суб' єктивна лексична частота і індекс Н - кращі предиктори у завданні найменування зображень. У завданні класифікації зображень на кількість реакцій, предикторними змінними були суб'єктивна лексична частота, концептуальна схожість та візуальна складність. Отримані результати обговорюються в поданій статті, з огляду на попередні наукові праці у цій сфері.

Ключові слова: психолінгвістичні змінні, предикторні змінні, найменування зображень, категоризація зображень, точність, кількість реакцій.

\section{Introduction}

The picture naming task (PNT) is one of the most used paradigms in psycholinguistics, cognitive psychology and neuropsychology. The aim of this task is to evoke the first name that comes to mind when a picture (e.g. object or action) is showed. For this task, the dependent variable is the elapsed time, measured in milliseconds, since the picture is presented until the subject begins to name it. Despite being a task that appears to be very simple, many successive cognitive processes, which under normal conditions are performed very quickly and automatically, are necessary. This is the most commonly used task to decide how mental representations could be retrieved from memory (Carroll \& White, 1973; Humphreys, Riddoch, \& Quinlan, 1988; Oldfield \& Wingfield, 1965; Snodgrass \& Yuditsky, 1996).

Previous studies have assessed the impact of psycholinguistic factors in PNT. Many factors could influence different stages, such as visual recognition, concept access or word retrieval. Characterize and quantify these factors in some variables would aid to identify which is the best predictor of accuracy and speed in healthy subjects' performance (Alario et al., 2004; Barry, Morrison, \& Ellis, 1997; Cuetos, Ellis, \& Alvarez, 1999; Manoiloff, Artstein, Canavoso, Fernández, \& Seguí, 2010). These factors should be similar across different languages but could be different depending on the material used (Khwaileh, Mustafawi, Herbert, \& Howard, 2018).

A less frequently employed but equally useful way to assess conceptual retrieval is picture categorization task (PCT). In PCT, subjects must classify stimuli into one of a set of categories (for example, dog as an ANIMAL or hammer as a TOOL). Categorization implies deciding whether an item belongs to certain classification (e.g. a semantic category or a semantic domain). In this task, it is possible to use pictures or words. PCT should appear to be easier than word categorization task since perceptual attributes provide information about the membership of the item to some semantic categories (e.g. the face or the legs in an animal and a handle or a blade in a tool).

The main variables identified which affect PNT are: visual complexity, conceptual familiarity, lexical frequency, name agreement, length, typicality and age of acquisition (Bakhtiar \& Weekes, 2015; Balota, Pilotti, \& Cortese, 2001; Barry, et 
al., 1997; Bates, Burani, D'amico, \& Barca, 2001; Cuetos, et al., 1999; Cycowicz, Friedman, Rothstein, \& Snodgrass, 1997; Khwaileh, et al., 2018; Laws, 1999; Snodgrass \& Vanderwart, 1980; Snodgrass \& Yuditsky, 1996; Székely \& Bates, 2000; Székely et al., 2003). In a PCT, the most frequently variables which affect subjects performance are: visual complexity, conceptual familiar, lexical frequency, typicality and age of acquisition (Barbón \& Cuetos, 2006; Morrison, Ellis, \& Quinlan, 1992). Until today, the best predictors for successful performance in picture naming and picture categorization are discussed.

Lexical frequency is a measure that denotes the degree of activation of a word. This variable refers to how frequent a word is activated in a specific language. It is associated with accuracy and speed in PNT. A word with higher frequency will be more accurately and quickly recovered (Humphreys, et al., 1988; Martein, 1995; Oldfield \& Wingfield, 1965). Oldfield and Wingfield (1965) identified, using a PNT with 26 pictures, a linear relationship between naming and latency times. They found a negatively correlation between naming latency and lexical frequency. This means that the names of pictures represented by words more frequently used are more available than the names that belong to words which are not so frequently used.

Age of acquisition (AoA) refers to the age at which a word is learned. The earlier a word is learned, the faster it is recovered and the higher accuracy in PNT is (Akinina et al., 2015; Bonin, Chalard, Méot, \& Fayol, 2002; Bonin, Peereman, Malardier, Méot, \& Chalard, 2003; Cameirão \& Vicente, 2010). AoA is frequently reported as highly correlated with lexical frequency. Words that are acquired earlier tend to be high frequency (Meschyan \& Hernandez, 2002). Carroll and White (1973) considered this variable a better predictor in PNT than lexical frequency. Moreover, AoA was the only significant variable in their multiple regression analysis to explain naming latencies times. Similar findings were reported by Morrison et al. (1992) using a multiple regression analysis with a PNT. In this study, the only variables that had significant effect in latencies times were AoA and the number of phonemes. Barry, Morrison and Ellis (1997) identified that speed naming was predicted by lexical frequency, the interaction between AoA and lexical frequency and name agreement. Also, Iyer et al. (2001) identified that the AoA was a slightly better predictor of latencies times than lexical frequency and also, by another variable, conceptual familiarity. They found a high correlation between AoA and latency times and also between latency times and lexical frequency. Moreover, in the same study, using a Stepwise Regression analysis, the authors identified that AoA and lexical frequency as independent variables. Some evidence suggests that the lexical frequency effect could also be partiality explained by the age of acquisition (Carroll \& White, 1973). The AoA effect was also present in pictures categorization task (Barbón \& Cuetos, 2006; Carroll \& White, 1973). Pictures that represent concepts learned earlier are categorized faster.

Visual complexity is one of the variables which could affect accuracy and also latency times (Ellis \& Morrison, 1998; Székely \& Bates, 2000). This variable refers to the numbers of lines and details included in the pictures. Nevertheless, some 
studies assessing picture naming in adults fail to identify visual complexity as a predictor variable in latency times (Barry, et al., 1997; Bonin, et al., 2002; Bonin, et al., 2003; Cuetos, et al., 1999; Khwaileh, Body, \& Herbert, 2014; Snodgrass \& Yuditsky, 1996), while others were able to identify it (D'amico, Devescovi, \& Bates, 2001; Shao, Roelofs, \& Meyer, 2012). The major problem is that visual complexity is frequently mistaken for another variables associated with the picture representation. In addition, it has been reported that visual complexity is negatively correlated with lexical frequency and conceptual familiarity and positively with AoA (Barry, et al., 1997; Cycowicz, et al., 1997; Ellis \& Morrison, 1998; Morrison, Chappell, \& Ellis, 1997; Sanfeliu \& Fernández, 1996; Snodgrass \& Vanderwart, 1980; Snodgrass \& Yuditsky, 1996). This means that pictures that are visually more complex are denoted by less frequent words and represented by less familiar concepts. Moreover, concepts representing more complex pictures are acquired later in life. Also, Cycowicz et al. (1997) identified that visual complexity ratings measured in young children for a set of 400 pictures did not differ from the adult's rating. This means that the conceptual familiarity or lexical frequency does not play a role when visual complexity ratings are measured.

Name agreement is another variable that predicts the performance in a PNT. This refers to the degree to which a concept is associated only to a specific name. Pictures with high name agreement were named with shorter latencies (Alario \& Ferrand, 1999; Barry, et al., 1997; Boukadi, Zouaidi, \& Wilson, 2016; MartínezCuitiño \& Vivas, In press).This variable is frequently negatively correlated with visual complexity. Snodgrass and Vanderwart (1980) identified that more visually complex pictures produce more alternative names (i.e. $\mathrm{H}$ value). This value is another measure regarding name agreement. When $\mathrm{H}$ is equal to 0 , a perfect name agreement is reached. When $\mathrm{H}$ value increases, the name agreement decreases. This correlation was replicated by Cycowicz et al. (1997) but others studies did not find it (Barry, et al., 1997; Bonin, et al., 2002; Bonin, et al., 2003; Cuetos, et al., 1999; Ellis \& Morrison, 1998; Sanfeliu \& Fernández, 1996; Snodgrass \& Yuditsky, 1996).

Conceptual familiarity refers to daily contact with an object or a concept within a specific language or culture. This variable predicts reaction times in PNT. Familiar concepts are retrieved faster (Akinina, et al., 2015; Boukadi, et al., 2016; Ellis \& Morrison, 1998; Snodgrass \& Yuditsky, 1996). Conceptual familiarity is strongly correlated with visual complexity and also with lexical frequency (Snodgrass \& Vanderwart, 1980). Because of the high correlation, Bates et al (2003) assumed that the frequency effect is a conceptual effect like conceptual accessibility. Almeida et al. (2007) considered that this measure affects the lexical level since it was presented in a PNT but it did not affect the semantic level, since it was absent in the categorization task.

Laws (1999) postulated that conceptual familiarity is a construct which includes a variety of concepts: conceptual, visual and functional familiarity. Laws and Neve (1999) identified that only visual familiarity is a good predictor in restricted picture naming tasks. But, until now, these findings have not been replicated. 
Another variable that could be a possible predictor in both tasks is the semantic domain. The pictures used in naming and categorization tasks represent living things (LT) and inanimate objects (IO). Differences in performance with both types of stimuli have been reported with neurological patients and control subjects (Albanese, Capitani, Barbarotto, \& Laiacona, 2000; Capitani, Laiacona, Barbarotto, \& Trivelli, 1994; Gaffan \& Heywood, 1993; Laws, 2000; Laws \& Neve, 1999; Lloyd-Jones \& Humphreys, 1997). Picture representations of LT and IO significantly vary in complexity: LT are visually more complex than IO (Laws, 2000), words representing LT are less frequent than the ones referring to IO (Warrington \& McCarthy, 1983), conceptual familiarity is higher for IO(Laws, 2000), and AoA between both domains is dissimilar.

Typicality is another variable to take into consideration. Typicality measures if an exemplar is representative of the other exemplars included in the same semantic category (e.g. tomato or lemon for the fruit category). More typical exemplars of a category are named and categorized faster (Martínez-Cuitiño \& Vivas, In press). Using a regression analysis, Morrison et al. (1992) identified that typicality was the only variable that predicted responses times.

The purpose of this work is to identify which variables are best predictors of the performance (accuracy and speed) of healthy participants in two tasks (naming and categorizing linear black-and-white pictures), employing a wide corpus of stimuli that belong to different semantic categories.

\section{Methods}

\subsection{Participants}

For this study, 48 participants were assessed in the picture naming task (30\% male and $70 \%$ female), with a mean age of 25.96 years $(S D=5.78)$. In the categorization task, 35 participants were evaluated ( $45.7 \%$ male and $54.3 \%$ female), with a mean age of 27.68 years $(S D=6.06)$.

All participants were undergraduate students, Spanish native speakers, and none of them suffered from alcoholism, drugs abuse, psychiatric or neurological diseases. All participants were right handed. They did not present visual impairments (or they had it corrected) by the time of the assessment (e.g. glasses or contact lenses). Participants took part of the study voluntarily and signed an informed consent to participate. They did not receive any money retribution for their collaboration. The study was conducted in agreement with the Declaration of Helsinki and approved by the institutional ethics' committee.

\subsection{Materials}

The 400 pictures from Cycowicz et al. (Cycowicz, et al., 1997) were used to design both tasks ${ }^{1}$. This set of stimuli has normative data for Argentine population

${ }^{1}$ In this material are included 260 black and white, simple pictures designed by Snodgrass and Vanderwart (1980) an also the pictures taken from Berman et al. (1989) 
(Manoiloff, et al., 2010; Martínez-Cuitiño, Barreyro, Wilson, \& Jaichenco, 2015). This set of pictures includes 108 LT and 292 IO.

\subsection{Procedure}

Participants were assessed during a 40-minute individual session for naming task, and a 20-minute session for categorization task. Both tasks were designed using the DMDX software (Forster \& Forster, 2003) and were administered in a 15inch-screen TOSHIBA laptop computer.

Stimuli were presented in a pseudo-random way, in four stages of 100 items each, with three breaks in between. For the naming task, items were counterbalanced according to initial phonemes (Székely, et al., 2003).

\subsection{Picture naming}

A practice with 10 items was presented before the task. A fixation point (*) appeared during 400 milliseconds (ms) on the screen. Then one picture was presented for $800 \mathrm{~ms}$. and, finally, a blank screen to name the picture was presented during $4000 \mathrm{~ms}$. This screen remained even if the subjects named the picture before the $800 \mathrm{~ms}$ had passed. No feedback was given regarding correct or wrong responses. Responses were subsequently analyzed with the Check Vocal program (Protopapas, 2007).

\subsection{Categorization task}

A practice with 10 items was presented before the task. A fixation point $(*)$ appeared during $400 \mathrm{~ms}$ on the screen, then one picture was presented for $800 \mathrm{~ms}$ and, finally, a blank screen appeared during $2000 \mathrm{~ms}$. Subjects were instructed to press the $\mathrm{S}$ key on the keyboard if the item belonged to the LT domain or the $\mathrm{N}$ key if it did not. If the participant pressed the key before the provided time was over, the next item was automatically presented. No feedback was given regarding correct or wrong responses.

\subsection{Data analysis}

A Pearson's $r$ correlation analysis was performed for picture naming and picture categorization considering the following variables: lexical frequency, conceptual familiarity, visual complexity, age of acquisition, $H$ index, correct answers and reaction times.

In order to identify predictive variables, a Path analysis was performed, using structural equation modeling. The analysis was executed by employing maximum likelihood estimate between measures as an input for the data analysis (Arbuckle, 2003). The model proposed and tested had two dependent variables: a) a categorization latent factor created from correct categorization answer and categorization reaction times and, b) a naming latent factor created from correct naming answer and naming latency times. The independent variables in the model were lexical frequency, conceptual familiarity, visual complexity, age of acquisition and $H$ index. The independent variables were correlated between them. 


\section{Results}

First, the descriptive statistics of the variables are presented en Table 1.

Table 1

Descriptive statistics

\begin{tabular}{lllllll}
\hline & $M$ & $S D$ & Min & Max & $S k$ & $K u$ \\
\hline CNA & 0,84 & 0,20 & 0,00 & 1,00 & $-1,61$ & 2,21 \\
NLT & 1127,02 & 287,75 & 682,97 & 2289,91 & 0,75 & 0,31 \\
CCA & 0,96 & 0,06 & 0,63 & 1,00 & $-2,03$ & 4,54 \\
CRT & 498,73 & 39,99 & 370,60 & 683,22 & 0,85 & 1,57 \\
LF & 2,59 & 1,22 & 1,03 & 5,00 & 0,49 & $-1,15$ \\
H & 0,79 & 0,72 & 0,00 & 2,66 & 0,67 & $-0,71$ \\
CF & 2,86 & 1,17 & 1,14 & 5,00 & 0,28 & $-1,27$ \\
AoA & 2,52 & 0,69 & 1,14 & 4,72 & 0,43 & $-0,12$ \\
VC & 3,14 & 0,96 & 1,00 & 4,94 & $-0,23$ & $-0,79$ \\
\hline
\end{tabular}

$\mathrm{CNA}=$ Correct naming answer, NLT $=$ Naming latency times, $\mathrm{CCA}=$ Correct categorization answer, $\mathrm{CRT}=$ Categorization reaction times; $\mathrm{LF}=$ Lexical Frequency, $\mathrm{H}=\mathrm{H}$ Index, $\mathrm{CF}=\mathrm{Concep}-$ tual Familiarity, AoA = Age of Acquisition; VC = Visual Complexity.

The results of correlation analysis between the variables and the results of the naming and categorization tasks are presented in Table 2.

Table 2

Correlations between variables and results in the naming and categorization tasks

\begin{tabular}{|c|c|c|c|c|c|c|c|c|c|}
\hline & CNA & NLT & CCA & CRT & LF & $\mathrm{H}$ & $\mathrm{CF}$ & AoA & $\mathrm{VC}$ \\
\hline CNA & 1 &,$- 80^{* * *}$ &,- 03 &,- 07 &, $18^{* * *}$ &,$- 29^{* * *}$ & $16^{* *}$ & ,03 & ,00 \\
\hline NLT & & 1 & ,06 &, $12^{*}$ &,$- 22^{* * *}$ &, $29^{* * *}$ &,$- 17^{* *}$ &,- 03 & ,02 \\
\hline CCA & & & 1 &,- 07 &, 00 & ,06 &, 03 &,- 04 &,- 01 \\
\hline CRT & & & & 1 &,$- 15^{* *}$ &, 06 &,$- 14^{* *}$ &, 02 &, $14^{* *}$ \\
\hline LF & & & & & 1 &,$- 19^{* * *}$ &, $84^{* * *}$ &,- 01 &,$- 34^{* * *}$ \\
\hline $\mathrm{H}$ & & & & & & 1 &,$- 15^{* *}$ &,- 03 & ,09 \\
\hline $\mathrm{CF}$ & & & & & & & 1 &,- 03 &,$- 41^{* * *}$ \\
\hline AoA & & & & & & & & 1 &, 03 \\
\hline
\end{tabular}

$\mathrm{CNA}=$ Correct naming answer, NLT $=$ Naming latency times, CCA $=$ Correct categorization answer, $\mathrm{CRT}=$ Categorization reaction times; $\mathrm{LF}=$ Lexical Frequency, $\mathrm{H}=\mathrm{H}$ Index, $\mathrm{CF}=$ Conceptual Familiarity, AoA = Age of Acquisition; VC = Visual Complexity.

Accuracy in naming task (CNA) is significantly and positively correlated with lexical frequency (LF) and conceptual familiarity (CF), and negatively with $\mathrm{H}$ index. The same results were found for reaction times (NLT). This implies that 
words with higher lexical frequency require less time to be retrieved, while words that were acquired later in life require more time. Also, words with higher conceptual familiarity and words with lower values in $\mathrm{H}$ index (higher name agreement) require less time.

Reaction times in categorization task (CRT) are negatively correlated with lexical frequency and conceptual familiarity, and positively with visual complexity (VC). In the categorization task, however, pictures with higher visual complexity, lower familiarity and lower lexical frequency required longer times to be categorized.

Subsequently, and with the aim of identify variables affecting naming and categorization of simple drawings, a path analysis was carried out (Arbuckle, 2003). The model showed a good adjustment of the data to the model $\left(\chi_{(14)}^{2}=21.24, p=\right.$ $\left..10, \chi^{2} / \mathrm{df}=1.52, \mathrm{CFI}=.99 ; \mathrm{TLI}=.98, \mathrm{AGFI}=.96 ; \mathrm{RMSEA}=.04\right)$. The model is presented in Figure 1.

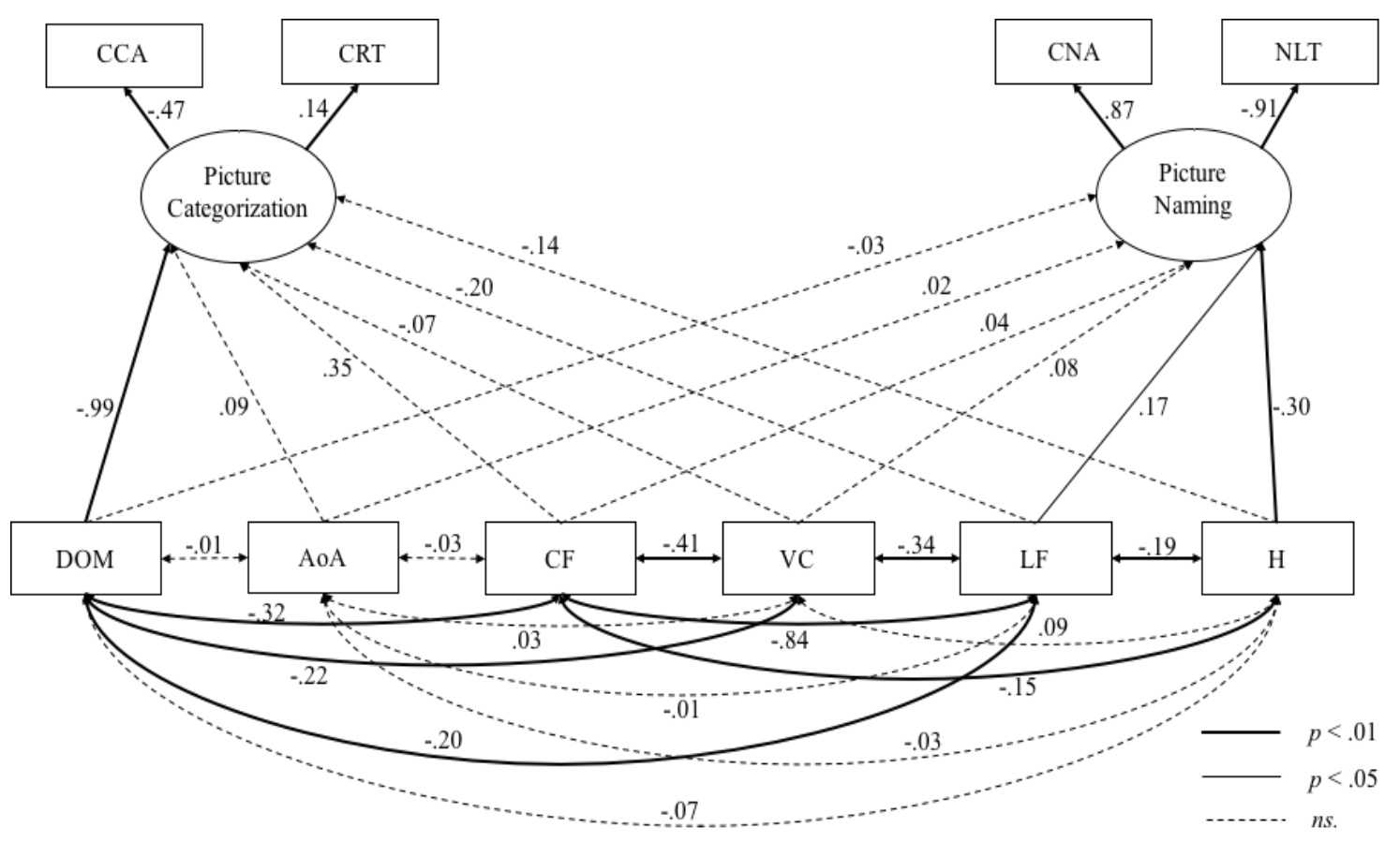

Fig. 1. Path Analysis Model proposed

The path analysis showed that the picture naming task is predicted by $\mathrm{H}$ index $(\beta=-.30 ; p<.001)$ and lexical frequency $(\beta=-.17 ; p<.05)$, and picture categorization is only predicted by semantic domain $(\beta=-.99 ; p<.01)$.

\section{Discussion}

The aim of this paper was to identify which psycholinguistic variables are the best predictors of performance (accuracy and speed) in naming and categorization tasks with healthy participants. We employed a wide corpus of stimuli (Cycowicz, et al., 1997) that belongs to different semantic categories. This material has normative data for Argentinian population. A correlation analysis was carried out, at 
first, to study relation among the variables, and a Path analysis (Arbuckle, 2003) was performed, consequently, to identify the better predictors.

The correlation analysis showed for both, accuracy and latency times in picture naming task, that the related variables are lexical frequency, conceptual familiarity and $\mathrm{H}$ index (name agreement). These results accord with the various previous findings in which the lexical frequency is associated with the accuracy and the reaction times in picture naming task (Alario, et al., 2004; Barry, et al., 1997; Cuetos, et al., 1999; Ellis \& Morrison, 1998; Khwaileh, et al., 2018; Martein, 1995; Oldfield \& Wingfield, 1965; Snodgrass \& Yuditsky, 1996). That means that the names of pictures represented by words more frequently used are more available than words which are not so frequently used. Also, these results accord with the findings reported about conceptual familiarity. Words that refer to more familiar concepts are retrieved faster than those related to less familiar concepts (Akinina, et al., 2015; Barca, Burani, \& Arduino, 2002; Boukadi, et al., 2016; Cuetos, et al., 1999; Ellis \& Morrison, 1998; Khwaileh, et al., 2018; Snodgrass \& Yuditsky, 1996).

The relation between $\mathrm{H}$ index and the accuracy and the latency time of picture naming was also identified in various previous studies (Alario, et al., 2004; Barry, et al., 1997; Bonin, et al., 2002; Bonin, et al., 2003; Boukadi, et al., 2016; Cuetos, et al., 1999; Cycowicz, et al., 1997; Dell'Acqua, Lotto, \& Job, 2000; Khwaileh, et al., 2014; Khwaileh, et al., 2018; Martínez-Cuitiño \& Vivas, In press; Snodgrass \& Yuditsky, 1996; Vitkovitch \& Tyrrell, 1995). The $\mathrm{H}$ index is a measure of name agreement, and that means that a word with low values of $\mathrm{H}$ index correlates to a high accuracy and fast latency time in naming. A picture with higher name agreement has less competition and this influences accuracy and naming latency.

In our study, age of acquisition shows no relation to accuracy and latency time in the picture naming task. These results are not in agreement with various of previous studies (Akinina, et al., 2015; Alario, et al., 2004; Barry, et al., 1997; Bonin, et al., 2002; Bonin, et al., 2003; Cameirão \& Vicente, 2010; Cuetos, et al., 1999; Dell'Acqua, et al., 2000; Khwaileh, et al., 2018; Meschyan \& Hernandez, 2002; Snodgrass \& Yuditsky, 1996) that classified the age of acquisition as a strong predictor variable. Words learned earlier have robust lexical representation. However, a possible explanation could be that in this study only 108 stimuli were LT. The OI are learned earlier. Perhaps this difference in the material could explain the absence of the age of acquisition effect because most lexical items in this set are acquired at earlier age therefore no AoA effect is found.

Our results also failed to detect a relation between visual complexity, accuracy and latency time in picture naming task. This accords with a major group of previous research (Barry, et al., 1997; Bonin, et al., 2002; Bonin, et al., 2003; Cuetos \& Barbón, 2006; Cuetos, et al., 1999; Snodgrass \& Yuditsky, 1996). Only some studies found this relation in French (Alario, et al., 2004) and in British English (Ellis \& Morrison, 1998).

The Path analysis showed that lexical frequency and $\mathrm{H}$ index are the best predictors for the picture naming task, but excluded the conceptual familiarity. Previous reports have suggested that conceptual familiarity is included within 
lexical frequency, so only the most robust variable of the two would show up in the analysis (Tanaka-Ishii \& Terada, 2011). That means only the most frequent words and with the lower $\mathrm{H}$ index are named more accurately and faster. In a previous research in French language (Alario, et al., 2004) that performed multiple regressions analyses, it was found that lexical frequency, age of acquisition, name agreement, image agreement, imageability and visual complexity are predictors for a picture naming task using the same pictures, but they did not find conceptual familiarity as a predictor. In Peninsular Spanish (Cuetos, et al., 1999), they spotted lexical frequency, age of acquisition, name agreement, image agreement, number of syllables, number of phonemes and conceptual familiarity as predictor variables.

According to previous studies, our results confirm that lexical frequency and name agreement are the best predictors for picture naming task. Conceptual familiarity and lexical frequency are independent measures although they are high related (Barry, et al., 1997; Bonin, Boyer, Méot, Fayol, \& Droit, 2004). Age of acquisition did not appear as a predictor. This is a rare result, since all previous studies identified the contribution of this variable to the naming times. Also, the impact of this variable had been identified across different languages (Bonin, et al., 2004; Brysbaert, Van Wijnendaele, \& De Deyne, 2000; Cameirão \& Vicente, 2010; Cuetos \& Barbón, 2006; Khwaileh, et al., 2018).

In the picture categorization task, the correlation analysis showed, only for reaction times, that the related variables are lexical frequency, conceptual familiarity and visual complexity. This means that the pictures with higher visual complexity, lower familiarity and lower lexical frequency require longer times to be categorized. In a previous study, Barbon \& Cuetos (2006) identified that the variables related to reaction times were lexical frequency, familiarity, age of acquisition and others not included in this study, such as imaginability and availability.

The Path analysis showed that semantic domain is the only predictor of the reaction times in the picture categorization task. Semantic domain (LT vs IO) predicts the speed of participants' performance. This variable, with the exception of Laws' study (2000), has not been taken as a possible predictor. Our data show that it is important to consider this variable, because IO domain is categorized more accurately and faster than LT. Categorization differs from naming because the subjects only have to recognize an item as belonging to certain category. This is not enough to respond in the naming task, where the subjects need to access the particular identity of an item and retrieve the exact name for a picture.

In both tasks, different variables affect the performance of participants. This means that both tasks are not similar and because of that, the variables that have an impact on a task are not the same that do so on the other. Considering this, it is possible to think that the cognitive processes involved in both tasks are different. A more thorough study could be necessary to detect the specific components and mechanisms involved in each task.

A limitation of this study is that all the results allow knowing in greater depth the psycholinguistic factors that predict the performance of young adults only. In a near 
future, it would be important to replicate these analyzes considering the performance of older adults in order to know if the same psycholinguistic variables are the predictors.

\section{References}

Akinina, Y., Malyutina, S., Ivanova, M., Iskra, E., Mannova, E., \& Dragoy, O. (2015). Russian normative data for 375 action pictures and verbs. Behavior research methods, 47(3), 691707. doi: $10.3758 / \mathrm{s} 13428-014-0492-9$

Alario, F. X., \& Ferrand, L. (1999). A set of 400 pictures standardized for French: Norms for name agreement, image agreement, familiarity, visual complexity, image variability, and age of acquisition. Behavior Research Methods, Instruments, \& Computers, 31(3), 531-552.

Alario, F. X., Ferrand, L., Lagnaro, M., New, B., Frauenfelder, U. H., \& Seguí, J. (2004). Predictors of picture naming speed. Behavior Research Methods, Instruments and Computers, 36, 140-155. doi: 10.3758/BF03195559

Albanese, E., Capitani, E., Barbarotto, R., \& Laiacona, M. (2000). Semantic category dissociations, familiarity and gender. Cortex, 36, 733-746.

Almeida, J., Knobel, M., Finkbeiner, M., \& Caramazza, A. (2007). The locus of the frequency effect in picture naming: When recognizing is not enough. Psychonomic Bulletin \& Review, 14(6), 1177-1182.

Arbuckle, J. L. (2003). AMOS 5.0. Chicago: SmallWaters.

Bakhtiar, M., \& Weekes, B. (2015). Lexico-semantic effects on word naming in Persian: Does age of acquisition have an effect? Memory \& Cognition, 43(2), 298-313. doi: 10.3758/s13421014-0472-4

Balota, D. A., Pilotti, M., \& Cortese, J. M. (2001). Subjective frequency estimates for 2,938 monosyllabic words. Memory \& Cognition, 29, 639-647. doi: 10.3758/BF03200465

Barbón, A., \& Cuetos, F. (2006). Efectos de la Edad de Adquisición en tareas de Categorización Semántica. Psicológica, 27, 207-223.

Barca, L., Burani, C., \& Arduino, L. (2002). Word naming times and psycholinguistic norms for Italian nouns. Behavior Research Methods, Instruments and Computers, 34(3), 424-434.

Barry, C., Morrison, C. M., \& Ellis, A. W. (1997). Naming the Snodgrass and Vanderwart pictures: Effects of age of acquisition, frequency and name agreement. Quarterly Journal of Experimental Psychology, 50(A), 560-585.

Bates, E., Burani, C., D'amico, S., \& Barca, L. (2001). Word reading and picture naming in Italian. Memory and Cognition, 29(7), 986-999.

Bates, E., D'Amico, S., Jacobsen, T., Székely, A., Andonova, E., Devescovi, A., . . Tzeng, O. (2003). Timed picture naming in seven languages. Psychonomic Bulletin \& Review 20(2), 344-380. doi: 10.3758/BF03196494

Berman, S., Friedman, D., Hamberger, M., \& Snodgrass, J. G. (1989). Developmental picture norms: Relationships between name agreement, familiarity, and visual complexity for child and adult ratings of two sets of line drawings. Behavior Research Methods, Instruments, \& Computers, 21(3), 371-382.

Bonin, P., Boyer, B., Méot, A., Fayol, M., \& Droit, S. (2004). Psycholinguistic norms for action photographs in French and their relationships with spoken and written latencies. Behavior Research Methods, Instruments, \& Computers, 36, 127-139. doi: 10.3758/BF03195558

Bonin, P., Chalard, M., Méot, A., \& Fayol, M. (2002). The determinants of spoken and written picture naming latencies. British Journal of Psychology, 93, 89-114. doi: 10.1348/ 000712602162463

Bonin, P., Peereman, R., Malardier, N., Méot, A., \& Chalard, M. (2003). A new set of 299 pictures for psycholinguistic studies: French norms for name agreement, image agreement, conceptual familiarity, visual complexity, image variability, age of acquisition and naming latencies. Behavior Research Methods, Instruments, \& Computers, 35, 158-167. 
Boukadi, M., Zouaidi, C., \& Wilson, M. A. (2016). Norms for name agreement, familiarity, subjective frequency, and imageability for 348 object names in Tunisian Arabic. Behavior Research Methods, 48, 585-599. doi: 10.3758/s13428-015-0602-3

Brysbaert, M., Van Wijnendaele, I., \& De Deyne, S. (2000). Age-of-acquisition effects in semantic processing tasks. Acta Psychologica, 104, 215-226. doi: 10.1016/S0001-6918(00)00021-4

Cameirão, M. L., \& Vicente, S. G. (2010). Age-of-acquisition norms for a set of 1,749 Portuguese words. Behavior Research Methods, 42, 474-480. doi: 10.3758/BRM.42.2.474

Capitani, E., Laiacona, M., Barbarotto, R., \& Trivelli, C. (1994). Living and nonliving categories: Is there a "normal" asymmetry? Neuropsychologia, 32, 1453-1463.

Carroll, J. B., \& White, M. N. (1973). Word frequency and age of acquisition as determiners of picture-naming latency. Quarterly Journal of Experimental Psychology, 25(1), 85-95. doi: $10.1080 / 14640747308400325$

Cuetos, F., \& Barbón, A. (2006). Word naming in Spanish. European Journal of Cognitive Psychology, 18, 415-436.

Cuetos, F., Ellis, A., \& Alvarez, B. (1999). Naming times for the Snodgrass and Vanderwart pictures in Spanish. Behavior Research Methods, Instruments and Computers, 31, 650-658. doi: 10.3758/BF03200741

Cycowicz, Y. M., Friedman, D., Rothstein, M., \& Snodgrass, J. G. (1997). Picture naming by young children: Norms for name agreement, familiarity, and visual complexity. Journal of Experimental Child Psychology, 65(2), 171-237. doi: 10.1006/jecp.1996.2356

D'amico, S., Devescovi, A., \& Bates, E. (2001). Picture naming and lexical access in italian children and adults. Journal of Cognition and Development, 2(1), 71-105.

Dell'Acqua, R., Lotto, L., \& Job, R. (2000). Naming times and standardized norms for the Italian PD/DPSS set of 266 pictures. Direct comparisons with American, English, French and Spanish published databases. Behavior Research Methods, Instruments, \& Computers, 31, 588-615.

Ellis, A. W., \& Morrison, C. M. (1998). Real age of acquisition effects in lexical retrieval. Journal of Experimental Psychology: Learning, Memory \& Cognition, 24, 515-523. doi: 10.1037/ 0278-7393.24.2.515

Forster, K. I., \& Forster, J. C. (2003). DMDX: A Windows display program with millisecond accuracy. Behavior Research Methods Instruments and Computers, 35, 116-124. doi: 10.3758/BF03195503

Gaffan, D., \& Heywood, C. (1993). A spurious category-specific visual agnosia for living things in normal human and nonhuman primates. Journal of Cognitive Neuroscience, 5(118-128). doi: 10.1162/jocn.1993.5.1.118

Humphreys, G. W., Riddoch, M. J., \& Quinlan, P. T. (1988). Cascade processes in picture identification. Cognitive Neuropsychology, 5(1), 67-103.

Iyer, G., Saccuman, C., Bates, E., \& Wulfeck, B. (2001). A Study of Age-of-acquisition (AoA) Ratings in Adults. CRL Newsletter, 13(2), 3-16.

Khwaileh, T., Body, R., \& Herbert, R. (2014). A normative database and determinants of lexical retrieval for 186 Arabic nouns: Effects of psycholinguistic and morpho-syntactic variables on naming latency. Journal of Psycholinguistic Research, 43, 749-769. doi: 10.1007/ s10936-013-9277-z

Khwaileh, T., Mustafawi, E., Herbert, R., \& Howard, D. (2018). Gulf Arabic nouns and verbs: A standardized set of 319 object pictures and 141 action pictures, with predictors of naming latencies. Behavior Research Methods, 50(6), 2408-2425. doi: 10.3758/s13428-018-1019-6

Laws, K. R. (1999). Gender afects latencies for naming living and nonliving things: implications for familiarity. Cortex, 35, 729-733.

Laws, K. R. (2000). Category-specificity naming errors in normal subjects: The influence of evolution and experience. Brain and Language, 75, 123-133. doi: 10.1006/brln.2000.2348

Laws, K. R., \& Neve, C. (1999). A `normal` category-specific advantage for naming living things. Neuropsychologia, 37, 1263-1269. doi: 10.1016/S0028-3932(99)00018-4 
Lloyd-Jones, T. J., \& Humphreys, G. W. (1997). Perceptual differentiation as a source of category effects in object processing: evidence from naming and object decision. Memory and Cognition, 25, 18-35 doi: 10.3758/BF03197282

Manoiloff, L., Artstein, M., Canavoso, M., Fernández, L., \& Seguí, J. (2010). Expanded norms for 400 experimental pictures in an Argentinean Spanish-speaking population. Behavior Research Methods, 42(2), 452-460. doi: 10.3758/BRM.42.2.452

Martein, R. (1995). Norms for name and concept agreement, familiarity, visual complexity and image agreement on a set of 216 pictures. Psychologica Belgica, 35, 205-225.

Martínez-Cuitiño, M., Barreyro, J. P., Wilson, M., \& Jaichenco, V. (2015). Nuevas normas semánticas y de tiempos de latencia para un set de 400 dibujos en español. Interdisciplinaria, 32(2), 289-305.

Martínez-Cuitiño, M., \& Vivas, L. (In press). Category or diagnosticity effect? The influence of color in picture naming tasks. Psychology and Neuroscience. doi: 10.1037/pne0000172

Meschyan, G., \& Hernandez, A. (2002). Age of acquisition and word frequency: Determinants of objectnaming speed and accuracy. Memory \& Cognition, 30, 262-269. doi: 10.3758/ BF03195287

Morrison, C. M., Chappell, T. D., \& Ellis, A. W. (1997). Age of Acquisition Norms for a Large Set of Object Names and Their Relation to Adult Estimates and Other Variables. The Quarterly Journal of Experimental Psychology Section A: Human Experimental Psychology, 50(3), 528-559. doi: 10.1080/027249897392017

Morrison, C. M., Ellis, A. W., \& Quinlan, P. T. (1992). Age of acquisition, not word frequency, affects object naming, not object recognition. Memory and Cognition, 20, 705-714. doi: 10.3758/BF03202720

Oldfield, R. C., \& Wingfield, A. (1965). Response latencies in naming objects. Quart J Exp Psychol, 17, 273-281. doi: 10.1080/17470216508416445

Protopapas, A. (2007). Check Vocal: A program to facilitate checking the accuracy and response time of vocal responses from DMDX. Behavior Research Methods, 39(4), 859-862. doi: 10.3758/BF03192979

Sanfeliu, M. C., \& Fernández, A. (1996). A set of 254 Snodgrass-Vanderwart pictures standardized for Spanish: Norms for name agreement, image agreement, familiarity, and visual complexity. Behavior Research Methods, Instruments, \& Computers, 28, 537-555.

Shao, Z., Roelofs, A., \& Meyer, A. S. (2012). Sources of individual differences in the speed of naming objects and actions: The contribution of executive control. The Quarterly Journal of Experimental Psychology, 65(10), 1927-1944.

Snodgrass, J. G., \& Vanderwart, M. (1980). A standardized set of 260 pictures: Norms for name agreement, image agreement, familiarity and visual complexity. Journal of Experimental Psychology: Human Learning and Memory, 6, 174-215. doi: 10.1037//0278-7393.6.2.174

Snodgrass, J. G., \& Yuditsky, T. (1996). Naming times for the Snodgrass and Vanderwart pictures. Behavior Research Methods, Instruments, y Computers, 28(4), 516-536.

Székely, A., \& Bates, E. (2000). Objective Visual Complexity as a Variable in Studies of Pictures Naming. CLR Newsletter, 12(2), 3-33.

Székely, A., D’Amico, S., Devescovi, A., Federmeier, K., Herron, D., Iyer, G., . . . Bates, E. (2003). Timed picture naming: Extended norms and validation against previous studies. Behavior Research Methods, Instruments, \& Computers, 35, 621-633. doi: 10.3758/ BF03195542

Tanaka-Ishii, K., \& Terada, H. (2011). Word familiarity and frequency. Studia Linguistica, 65(1), 96-116. doi: 10.1111/j.1467-9582.2010.01176.x

Vitkovitch, M., \& Tyrrell, L. (1995). Sources of disagreement in object naming. Quarterly Journal of Experimental Psychology, 48(A), 822-848. doi: 10.1080/14640749508401419

Warrington, E. K., \& McCarthy, R. A. (1983). Category-specific access dysphasia. Brain, 106, 859-879. doi: 10.1093/brain/106.4.859 